\title{
Glaciers, glacial lakes and glacial lake outburst floods in the Mount Everest region, Nepal
}

\author{
Samjwal Ratna BAJRACHARYA, Pradeep MOOL \\ International Centre for Integrated Mountain Development (ICIMOD), GPO Box 3226, Khumaltar, Kathmandu, Nepal \\ E-mail: sabajracharya@icimod.org
}

\begin{abstract}
Recent climate changes have had a significant impact on the high-mountain glacial environment. Rapid melting of glaciers has resulted in the formation and expansion of moraine-dammed lakes, creating a potential danger from glacial lake outburst floods (GLOFs). Most lakes have formed during the second half of the 20th century. Glaciers in the Mount Everest (Sagamartha) region, Nepal, are retreating at an average rate of $10-59 \mathrm{~m} \mathrm{a}^{-1}$. From 1976 to 2000, Lumding and Imja Glaciers retreated 42 and $34 \mathrm{~m} \mathrm{a}^{-1}$, respectively, a rate that increased to $74 \mathrm{~m} \mathrm{a}^{-1}$ for both glaciers from 2000 to 2007. During the past decade, Himalayan glaciers have generally been shrinking and retreating faster while moraine-dammed lakes have been proliferating. Although the number of lakes above $3500 \mathrm{~m}$ a.s.l. has decreased, the overall area of moraine-dammed lakes is increasing. Understanding the behaviour of glaciers and glacial lakes is a vital aspect of GLOF disaster management.
\end{abstract}

\section{INTRODUCTION}

Dudh Koshi basin in eastern Nepal is one of the country's largest and most important basins in terms of glaciers and glacial lakes, and probably the most densely glacierized region of Nepal (Bajracharya and others, 2007). The glaciers extend to latitude $27^{\circ} 38^{\prime} 05^{\prime \prime} \mathrm{N}$ and $4206 \mathrm{~m}$ a.s.l., although the termini of most are at about $5000 \mathrm{~m}$ a.s.l. The largest glacier in this basin is Ngojumba Glacier with an area of $82.61 \mathrm{~km}^{2}$; however, the largest glacier in Nepal is Kanchenjunga Glacier with an area of $94.52 \mathrm{~km}^{2}$. Changes in mountain glaciers are among the best natural indicators of climate change (Oerlemans, 1994; Houghton and others, 2001) and there has been a significant impact on this highmountain glacial environment. The glaciers are melting rapidly (Fujita and others, 2001), leading to the formation of new glacial lakes, the expansion of existing morainedammed lakes and the potential for glacial lake outburst floods (GLOFs) (Watanabe and others, 1994). Most of the lakes, above $3500 \mathrm{~m}$ a.s.l., formed in response to warming temperatures during the second half of the 20th century (Yamada and Sharma, 1993; Mool and others, 2001). The largest of the lakes is Imja Tsho with an area of about $0.95 \mathrm{~km}^{2}$, recorded as one of the fastest-growing lakes in the entire Himalaya (Bajracharya and others, 2007). Understanding the response of glaciers and glacial lakes to rising temperatures is an essential aspect of planning water resources as well as managing the potential for GLOF disasters.

\section{METHODS}

The threshold ratio from Thematic Mapper (TM) band 4 and 5 images has been used widely for glacier delineation. This technique is simple, robust and accurate and has been applied to the 2000 Swiss glacier inventory and others (Sidjak and Wheate, 1999; Albert, 2002; Paul, 2002; Paul and others, 2004; Bolch and others, 2008). Although the overall delineation of glaciers was carried out using this method, manual digitizing of sources from different years was used for the specific analysis of glacier change presented here: topographic maps (1960s), Landsat Multispectral scanner (MSS) (1976), Landsat TM (1992), Landsat Enhanced TM Plus
(ETM+) (2001) and Advanced Land Observing Satellite (ALOS) (2007). Due to limitations in the remote-sensing imagery (e.g. shadows, coarse resolution), the number of valley glaciers studied to identify their retreat rate was limited to 22. Glacier length was obtained in the geo-referenced images from the difference between the highest and lowest elevations. As it was difficult to identify the smaller lakes in the coarse-resolution satellite images (Bolch and others, 2008), the number of small erosion and supraglacial lakes decreased significantly compared with the 1960s. However, the area of Imja Tsho, derived from a manual delineation based on the 2000 Landsat scene, was $0.77 \mathrm{~km}^{2}$, whereas its area derived from a classification of the same Landsat scene was $0.766 \mathrm{~km}^{2}$ (Bolch and others, 2008), indicating some consistency between the two methods.

\section{GLACIERS AND GLACIER RETREAT}

The number of glaciers mapped in the basin was 278 with a total area of $482 \mathrm{~km}^{2}$ and an ice volume of $51 \mathrm{~km}^{3}$ (Mool and others, 2001). Although they are located in the high mountains (Fig. 1), 40 glaciers, accounting for $70 \%$ of the glacierized area, extend down into the valley. Ngojumba, Khumbu, Bhote Koshi and Hungu glaciers are the principal glaciers in the Dudh Koshi basin and have areas of 82.61, $45.39, \quad 35.63$ and $22.91 \mathrm{~km}^{2}$, respectively. The average minimum retreat rate was $10 \mathrm{~m} \mathrm{a}^{-1}$, observed on Langdak, West Lhotse, Lhotse and Setta glaciers. Imja Glacier retreated at $34 \mathrm{ma}^{-1}$ from 1962 to 2000, a rate that increased to $74 \mathrm{~m} \mathrm{a}^{-1}$ from 2000 to 2007, giving an overall average retreat rate of $59 \mathrm{~m} \mathrm{a}^{-1}$; it is now one of the fastestretreating glaciers in the Himalaya. Other rapidly retreating glaciers are West Chamiang and Ombigaichain (Table 1; Fig. 2). In general, glaciers have been shrinking and retreating faster in the present decade (2000-07); Khromova and others, 2003; Paul and others, 2004).

\section{GLACIAL LAKES AND LAKE ACTIVITY}

There are 473 glacial lakes $>0.003 \mathrm{~km}^{2}$ situated above 3500 ma.s.l. in the Dudh Koshi basin (Mool and others, 


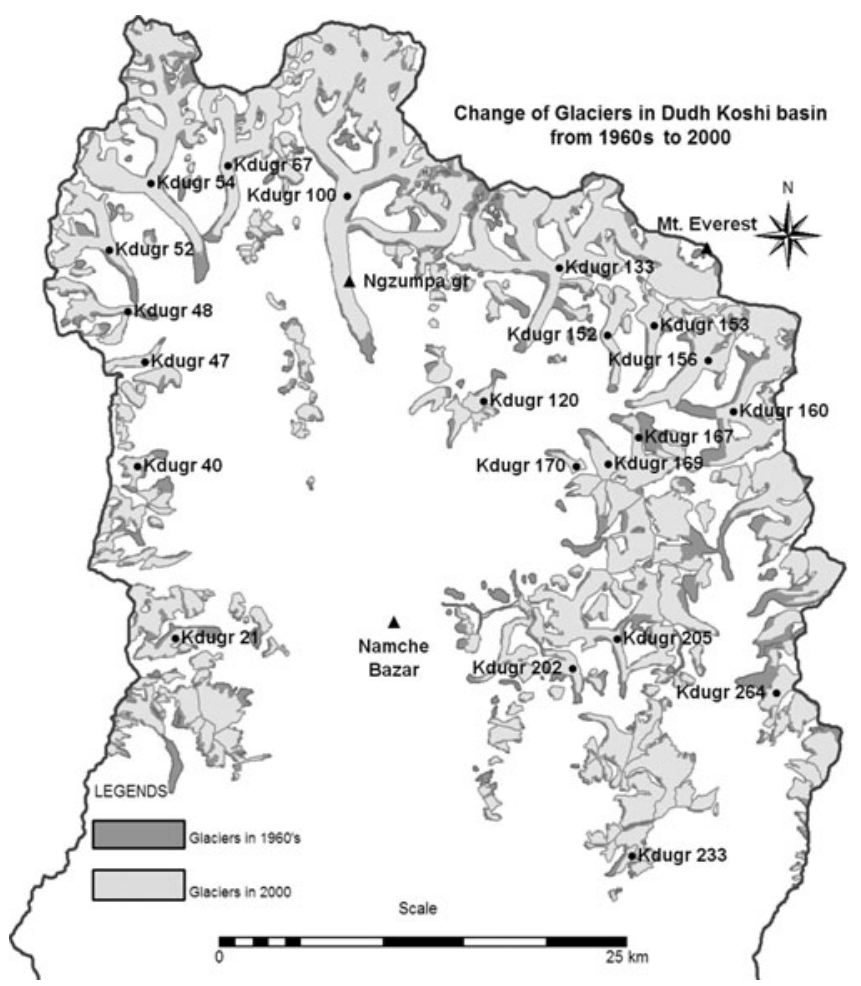

Fig. 1. Change in glaciers in the Dudh Koshi basin from the 1960s to 2000 .
2001). The most important of these are Lumding Tsho, Dig Tsho, Imja Tsho, Tam Pokhari, Dudh Pokhari, Hungu and Chamiang.

In a recent study, Bajracharya and Mool (2005) mapped 296 lakes from 2001 Landsat ETM+. They found that the lakes that had disappeared were mostly the supraglacial and erosion lakes. Most of the former were either too small to map (Bolch and others, 2008) or had disappeared; some had been transformed into moraine-dammed lakes. While there had been a $37 \%$ decline in the number of lakes, the total area of lakes increased by $21 \%$, due to the proliferation of moraine-dammed lakes. Of the major lakes (defined as $>0.02 \mathrm{~km}^{2}$ ), 34 were increasing in size and 24 new ones had appeared. The latter consisted of 15 moraine-dammed lakes, five supraglacial lakes, two valley lakes (lakes in the flood plain) and two erosion lakes (lakes on the valley slopes) (Table 2). Areas of these major glacial lakes, which lie at 4349-5636 m a.s.l., ranged from 0.021 to $0.848 \mathrm{~km}^{2}$.

The fast and continuous retreat of glaciers and growth of glacial lakes highlights the need to monitor glaciers and glacial lakes for the sound management of water resources. However, study of this phenomenon is a challenge because of the limits imposed by high altitude, the rarefied atmosphere, the remoteness of many of the locations and the short mapping season.

This is partly reflected in Table 3 which shows the growth rate of the lakes. From 2000 to 2007 the values are mostly negative because the image used for the analysis was from January 2007, a time of the year when most of the lakes at high altitude are frozen and at their minimum extent; however, some (e.g. lakes 71 and 543) showed significant growth.

Table 1. Retreat rate of valley glaciers in the Dudh Koshi basin

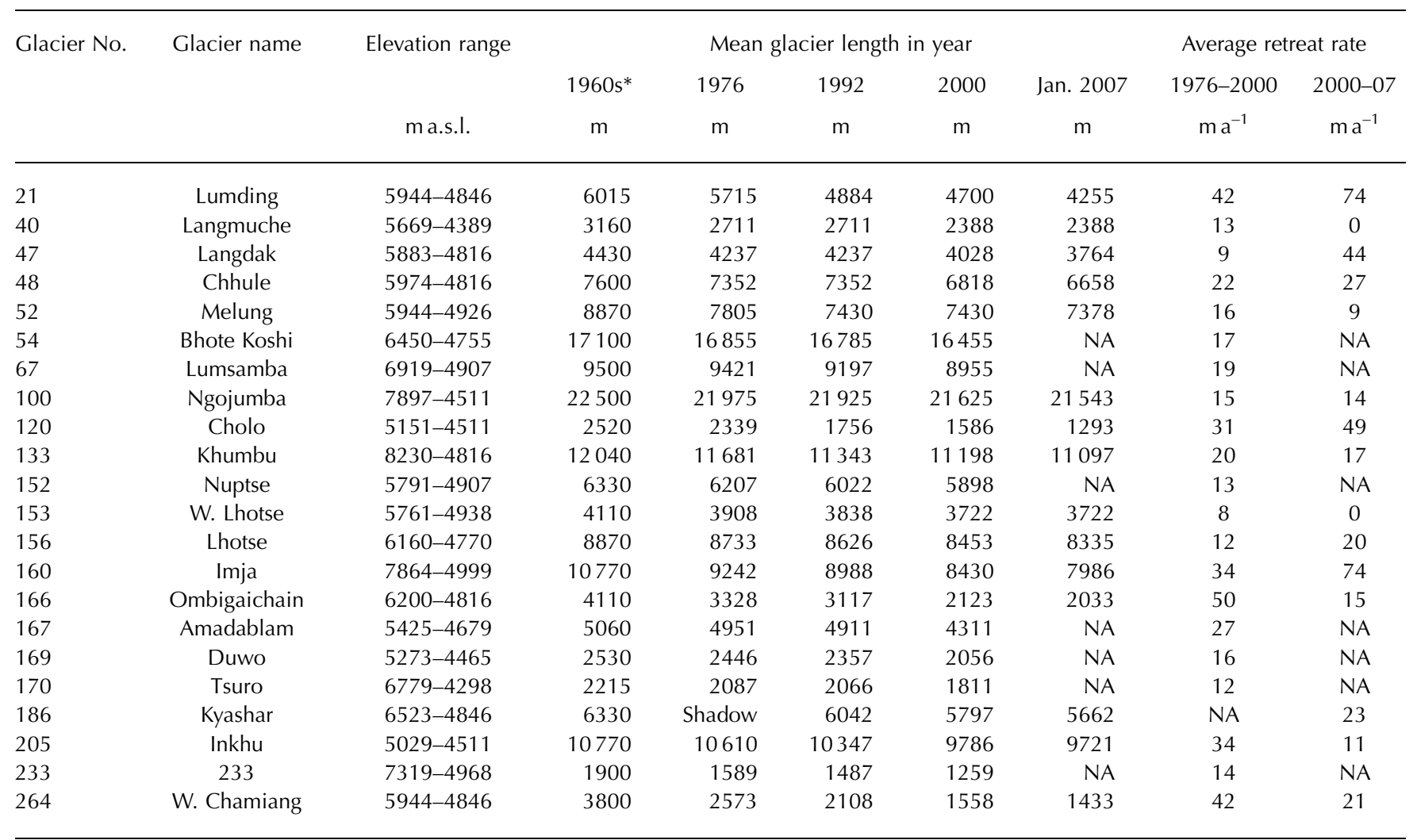

*1960s data are from topographic maps published by the Survey of India;.

NA: not available. 

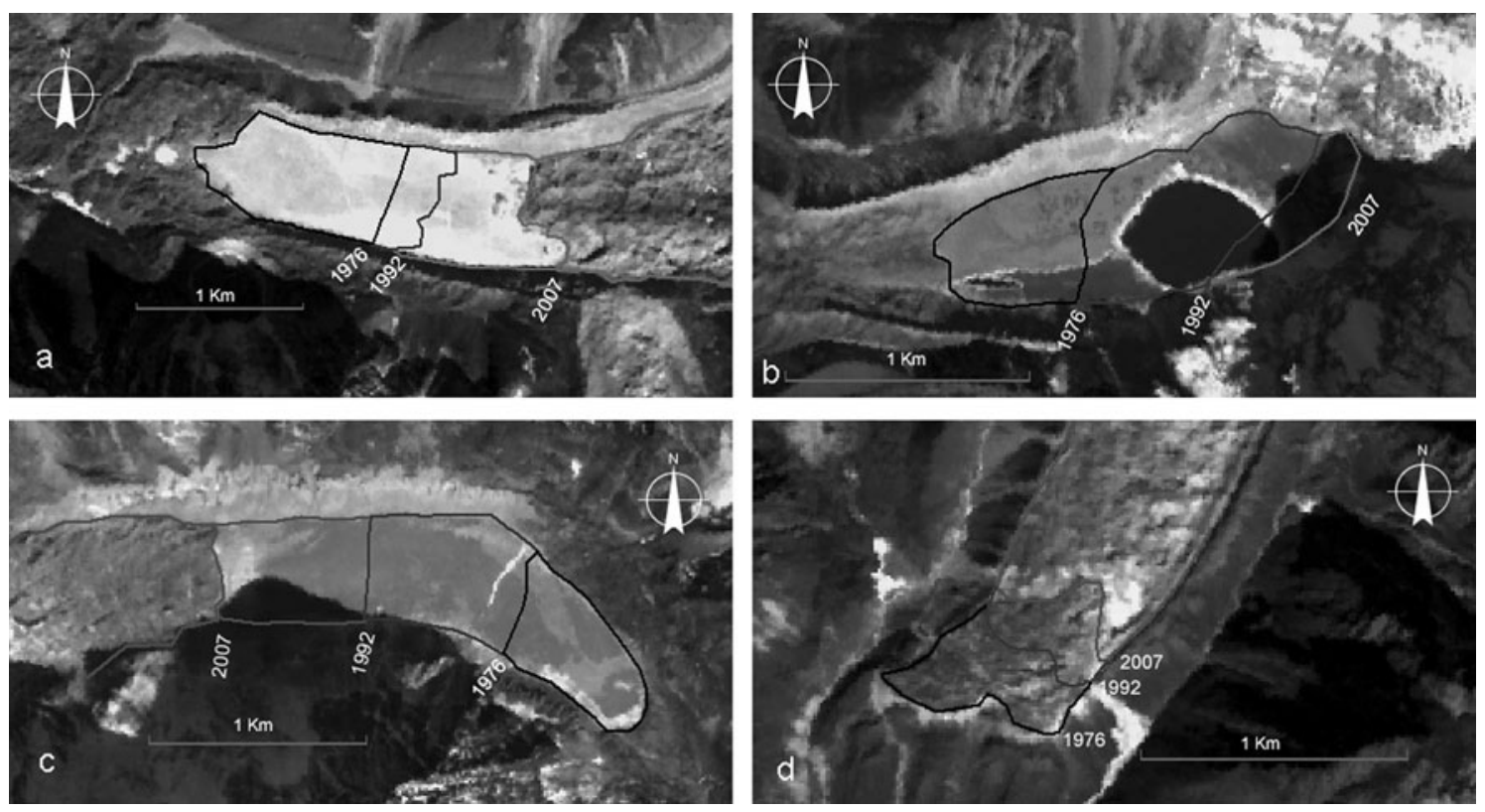

Fig. 2. Examples of glacier retreat and lake expansion from the Dudh Koshi basin: (a) Imja Glacier and Tsho; (b) glacier 262 (lake 464 ) in Hungu valley; (c) Lumding Glacier and Tsho; (d) Khumbu Glacier.

\section{POTENTIALLY DANGEROUS GLACIAL LAKES}

Rapid retreat of glaciers increases run-off, contributes to the growth of glacial lakes and converts some supraglacial lakes to moraine-dammed lakes (Hambrey and others, 2008). These lakes tend to breach the weak and unstable loose moraine dam (Yamada and Sharma, 1993; Watanabe and others, 1995), with catastrophic impacts downstream. Amongst the numerous glaciers and glacial lakes, the basin includes 12 potentially dangerous glacial lakes, the largest number in any sub-basin of Nepal, all of which (except lake 444) are dammed by loose and unstable moraine. Of the potentially dangerous glacial lakes identified (Table 4), three (lakes 422, 442 and 462) have remained at approximately the same size, one (lake 444) dried up in 2001 but subsequently reappeared, Tam Pokhari (lake 399) and Dig Tsho (lake 55) have a GLOF history, while the remaining six lakes (28, 350, 449, 459, 464 and 466) are growing. Imja Tsho (lake 350) is one of the fastest-growing lakes in the Himalaya.

Lake 444 was identified by Mool and others (2001) as a potentially dangerous glacial lake in 2000, but later that year had dried up or completely drained, reappearing again in 2007 (Bajracharya and others, 2007) with an area of $25376 \mathrm{~m}^{2}$ (Table 4). It is a valley lake separated from the glacier. The risk of a GLOF from lake 444, compared with other lakes in the Dudh Koshi basin is considered to be sufficiently small that it should be removed from the list.

Dig Tsho (lake 55) had an outburst event in 1985 after which the lake area was reduced to $0.3 \mathrm{~km}^{2}$ with maximum depth $>10 \mathrm{~m}$ (more details are given below). The lake is surrounded by thick moraine on two sides, the steep-sloping Langmoche Glacier to the west and the lake outlet to the east. Analysis of temporal satellite images and field observations shows that the extreme end of the lake abuts the steep snout of Langmoche Glacier and there is no possibility for further expansion of the lake. As the present lake outlet is at the same level as the bed of the Langmoche river (Fig. 3), it can be concluded that Dig Tsho is no longer a potentially dangerous lake, as indicated in the 2001 inventory by the International Centre for Integrated Mountain Development (ICIMOD) and United Nations Environment Programme (UNEP).

\section{GLACIAL LAKE OUTBURST FLOODS}

Fast glacier retreat during the past decade has resulted in the rapid accumulation of meltwater in most of the moraine-dammed lakes in the basin, has increased their potential energy and reduced the shear strength of the damming material. Ultimately the loose-moraine dam will be breached, causing a GLOF (Ives, 1986; Zimmermann and others, 1986; Yamada, 1998; Richardson and

Table 2. State of glacial lakes in the Dudh Koshi basin (1960-2000)

\begin{tabular}{ll}
\hline 1. Disappeared $($ or $<50 \times$ & $50 \mathrm{~m}^{2}$ ) lakes \\
& Supraglacial \\
& Erosion \\
Valley & \\
Moraine-dammed & \\
Cirque &
\end{tabular}

2. Converted lakes (from supraglacial to morainedammed lakes)

3. New lakes

$\begin{array}{lr}\text { Supraglacial } & 5 \\ \text { Erosion } & 2 \\ \text { Valley } & 2 \\ \text { End moraine-dammed } & 15 \\ & \\ \text { Supraglacial } & 10 \\ \text { Valley } & 2 \\ \text { Moraine-dammed } & 17 \\ \text { Blocked } & 2 \\ \text { Erosion } & 3\end{array}$


Table 3. Activity of glacial lakes in the Dudh Koshi basin

\begin{tabular}{|c|c|c|c|c|c|c|c|c|}
\hline \multirow{3}{*}{$\begin{array}{l}\text { Lake } \\
\text { No. }\end{array}$} & \multirow[t]{3}{*}{ Location } & \multirow[t]{3}{*}{ Type } & \multicolumn{3}{|c|}{ Average area in year } & \multirow{3}{*}{$\begin{array}{c}\text { Distance to } \\
\text { glacier } \\
\text { m }\end{array}$} & \multicolumn{2}{|c|}{ Average growth rate } \\
\hline & & & $1960 \mathrm{~s}$ & 2000 & 2007 & & $1960 s-2000$ & 2000-07 \\
\hline & & & $\mathrm{m}^{2}$ & $\mathrm{~m}^{2}$ & $\mathrm{~m}^{2}$ & & $\%$ & $\%$ \\
\hline 40 & $27^{\circ} 47^{\prime} 44^{\prime} \mathrm{N}, 86^{\circ} 37^{\prime} 14^{\prime} \mathrm{E}$ & Moraine-dammed & 18914 & 23289 & 22319 & 270 & 23 & -4 \\
\hline 43 & $27^{\circ} 47^{\prime} 09^{\prime} \mathrm{N}, 86^{\circ} 38^{\prime} 06^{\prime} \mathrm{E}$ & Moraine-dammed & 13662 & 25888 & 26721 & 70 & 89 & 3 \\
\hline 47 & $27^{\circ} 49^{\prime} 14^{\prime} \mathrm{N}, 86^{\circ} 35^{\prime} 38^{\prime} \mathrm{E}$ & Blocked & 12866 & 35593 & Shadow & 45 & 177 & NA \\
\hline 52 & $27^{\circ} 49^{\prime} 38^{\prime} \mathrm{N}, 86^{\circ} 34^{\prime} 38^{\prime} \mathrm{E}$ & Moraine-dammed & 2096 & 30921 & 33131 & 785 & 1375 & 7 \\
\hline 69 & $27^{\circ} 57^{\prime} 06^{\prime} \mathrm{N}, 86^{\circ} 34^{\prime} 44^{\prime} \mathrm{E}$ & Supraglacial & 3316 & 23322 & 19168 & 0 & 603 & -18 \\
\hline 71 & $27^{\circ} 56^{\prime} 39^{\prime} \mathrm{N}, 86^{\circ} 33^{\prime} 15^{\prime} \mathrm{E}$ & Supraglacial & 4404 & 21194 & 54101 & 300 & 381 & 155 \\
\hline 160 & $27^{\circ} 57^{\prime} 38^{\prime} \mathrm{N}, 86^{\circ} 39^{\prime} 58^{\prime} \mathrm{E}$ & Erosion & 15439 & 27473 & 24488 & 670 & 78 & -11 \\
\hline 229 & $27^{\circ} 56^{\prime} 03^{\prime} \mathrm{N}, 86^{\circ} 44^{\prime} 42^{\prime} \mathrm{E}$ & Erosion & 17933 & 20184 & 22210 & 515 & 13 & 10 \\
\hline 255 & $27^{\circ} 57^{\prime} 23^{\prime} \mathrm{N}, 86^{\circ} 48^{\prime} 37^{\prime} \mathrm{E}$ & Supraglacial & 10425 & 48496 & 12284 & 0 & 365 & -75 \\
\hline 287 & $27^{\circ} 59^{\prime} 51^{\prime} \mathrm{N}, 86^{\circ} 50^{\prime} 20^{\prime} \mathrm{E}$ & Supraglacial & 48811 & 121762 & 121999 & 0 & 149 & 0 \\
\hline 300 & $27^{\circ} 57^{\prime} 38^{\prime} \mathrm{N}, 86^{\circ} 50^{\prime} 06^{\prime} \mathrm{E}$ & Block/valley & 16606 & 23474 & 22110 & 95 & 41 & -6 \\
\hline 342 & $27^{\circ} 55^{\prime} 08^{\prime} \mathrm{N}, 86^{\circ} 54^{\prime} 50^{\prime} \mathrm{E}$ & Supraglacial & 6977 & 41503 & 9144 & 0 & 495 & -78 \\
\hline 384 & $27^{\circ} 53^{\prime} 09^{\prime} \mathrm{N}, 86^{\circ} 50^{\prime} 50^{\prime} \mathrm{E}$ & Moraine-dammed & 14431 & 29750 & 23711 & 245 & 106 & -20 \\
\hline 446 & $27^{\circ} 49^{\prime} 58^{\prime} \mathrm{N}, 86^{\circ} 55^{\prime} 18^{\prime} \mathrm{E}$ & Moraine-dammed & 207314 & 349263 & 357903 & 0 & 68 & 2 \\
\hline 472 & $27^{\circ} 42^{\prime} 40^{\prime} \mathrm{N}, 86^{\circ} 58^{\prime} 48^{\prime} \mathrm{E}$ & Moraine-dammed & 6526 & 46215 & 49900 & 0 & 608 & 8 \\
\hline 483 & $27^{\circ} 43^{\prime} 39^{\prime} \mathrm{N}, 86^{\circ} 34^{\prime} 22^{\prime} \mathrm{E}$ & Moraine-dammed & New & 34016 & 32040 & 0 & NA & -6 \\
\hline 491 & $27^{\circ} 46^{\prime} 39^{\prime} \mathrm{N}, 86^{\circ} 38^{\prime} 44^{\prime} \mathrm{E}$ & Moraine-dammed & New & 286119 & 305913 & 245 & NA & 7 \\
\hline 495 & $27^{\circ} 54^{\prime} 32^{\prime} \mathrm{N}, 86^{\circ} 35^{\prime} 00^{\prime} \mathrm{E}$ & Moraine-dammed & New & 20044 & 23582 & 405 & NA & 18 \\
\hline 501 & $27^{\circ} 57^{\prime} 30^{\prime} \mathrm{N}, 86^{\circ} 39^{\prime} 50^{\prime} \mathrm{E}$ & Moraine-dammed & New & 60039 & 38937 & 270 & NA & -35 \\
\hline 502 & $27^{\circ} 59^{\prime} 20^{\prime} \mathrm{N}, 86^{\circ} 39^{\prime} 06^{\prime} \mathrm{E}$ & Moraine-dammed & New & 58097 & 55811 & 0 & NA & -4 \\
\hline 505 & $27^{\circ} 56^{\prime} 10^{\prime} \mathrm{N}, 86^{\circ} 42^{\prime} 48^{\prime} \mathrm{E}$ & Supraglacial & New & 48184 & 56412 & 0 & NA & 17 \\
\hline 511 & $27^{\circ} 59^{\prime} 27^{\prime} \mathrm{N}, 86^{\circ} 41^{\prime} 38^{\prime} \mathrm{E}$ & Supraglacial & New & 27858 & 18444 & 0 & NA & -34 \\
\hline 513 & $28^{\circ} 02^{\prime} 30^{\prime} \mathrm{N}, 86^{\circ} 42^{\prime} 31^{\prime} \mathrm{E}$ & Moraine-dammed & New & 38349 & 32060 & 210 & NA & -16 \\
\hline 517 & $27^{\circ} 48^{\prime} 38^{\prime} \mathrm{N}, 86^{\circ} 50^{\prime} 52^{\prime} \mathrm{E}$ & Moraine-dammed & New & 69238 & 66056 & 0 & NA & -5 \\
\hline 524 & $27^{\circ} 42^{\prime} 49^{\prime} \mathrm{N}, 86^{\circ} 55^{\prime} 12^{\prime} \mathrm{E}$ & Moraine-dammed & New & 67607 & 66011 & 310 & NA & -2 \\
\hline 526 & $27^{\circ} 43^{\prime} 28^{\prime} \mathrm{N}, 86^{\circ} 54^{\prime} 13^{\prime} \mathrm{E}$ & Moraine-dammed & New & 31381 & 34001 & 170 & NA & 8 \\
\hline 528 & $27^{\circ} 49^{\prime} 26^{\prime} \mathrm{N}, 86^{\circ} 55^{\prime} 54^{\prime} \mathrm{E}$ & Moraine-dammed & New & 46225 & 36571 & 880 & NA & -21 \\
\hline 536 & $27^{\circ} 58^{\prime} 08^{\prime} \mathrm{N}, 86^{\circ} 42^{\prime} 05^{\prime} \mathrm{E}$ & Supraglacial & New & 27084 & 19604 & 0 & NA & -28 \\
\hline 543 & $27^{\circ} 45^{\prime} 57^{\prime} \mathrm{N}, 86^{\circ} 52^{\prime} 31^{\prime} \mathrm{E}$ & Supraglacial & New & 21467 & 44821 & 0 & NA & 109 \\
\hline
\end{tabular}

Notes: Due to different satellite images and projection parameters the accuracy of the data varies from 90 to $95 \%$,. NA: not available.

Table 4. Status of potentially dangerous glacial lakes in the Dudh Koshi basin in 2007

\begin{tabular}{|c|c|c|c|c|c|c|c|c|c|c|}
\hline \multirow{3}{*}{$\begin{array}{l}\text { Lake } \\
\text { No. }\end{array}$} & \multirow[t]{3}{*}{ Name } & \multirow[t]{3}{*}{ Location } & \multirow{3}{*}{$\begin{array}{l}\text { Altitude } \\
\text { ma.s.l. }\end{array}$} & \multicolumn{3}{|c|}{ Average length in year } & \multicolumn{3}{|c|}{ Average area in year } & \multirow[t]{3}{*}{ Remarks } \\
\hline & & & & $1960 \mathrm{~s}$ & 2000 & 2007 & $1960 \mathrm{~s}$ & 2000 & 2007 & \\
\hline & & & & $\mathrm{m}$ & $\mathrm{m}$ & $\mathrm{m}$ & $\mathrm{m}^{2}$ & $\mathrm{~m}^{2}$ & $\mathrm{~m}^{2}$ & \\
\hline 28 & Lumding Tsho & $27^{\circ} 46.51^{\prime} \mathrm{N}, 86^{\circ} 37.53^{\prime} \mathrm{E}$ & 4846 & 625 & 1952 & 2180 & 104944 & 836765 & 940077 & Growing \\
\hline 55 & Dig Tsho & $27^{\circ} 52.41^{\prime} \mathrm{N}, 86^{\circ} 36.61^{\prime} \mathrm{E}$ & 4364 & 605 & 1262 & 1263 & 143250 & 375681 & 403044 & $\begin{array}{c}\text { GLOF on } 4 \text { Aug. 1985, no } \\
\text { danger }\end{array}$ \\
\hline 350 & Imja Tsho & $27^{\circ} 54.00^{\prime} \mathrm{N}, 86^{\circ} 55.40^{\prime} \mathrm{E}$ & 5023 & 410 & 1822 & 2027 & 48811 & 848742 & 945662 & Rapidly growing \\
\hline 399 & Tam Pokhari & $27^{\circ} 44.33^{\prime} \mathrm{N}, 86^{\circ} 50.76^{\prime} \mathrm{E}$ & 4431 & 515 & 925 & 898 & 138846 & 265386 & 255495 & GLOF on 3 Sep. 1998 \\
\hline 422 & Dudh Pokhari & $27^{\circ} 41.21^{\prime} \mathrm{N}, 86^{\circ} 51.68^{\prime} \mathrm{E}$ & 4760 & 1120 & 1095 & 1159 & 274297 & 297574 & 316767 & No change in area \\
\hline 442 & Unnamed & $27^{\circ} 47.70^{\prime} \mathrm{N}, 86^{\circ} 54.81^{\prime} \mathrm{E}$ & 5266 & 840 & 1082 & 1075 & 133753 & 194966 & 188559 & No change in area \\
\hline 444 & Unnamed & $27^{\circ} 48.23^{\prime} \mathrm{N}, 86^{\circ} 56.61^{\prime} \mathrm{E}$ & 5056 & 420 & 0 & 235 & 112398 & 0 & 25376 & Dried/reappeared, no danger \\
\hline 449 & Hungu & $27^{\circ} 50.17^{\prime} \mathrm{N}, 86^{\circ} 56.26^{\prime} \mathrm{E}$ & 5181 & 875 & 1054 & 1327 & 198905 & 232842 & 267720 & Merged with lake 532 \\
\hline 459 & East Hungu 1 & $27^{\circ} 47.92^{\prime} \mathrm{N}, 86^{\circ} 57.95^{\prime} \mathrm{E}$ & 5379 & 465 & 982 & 1105 & 78761 & 296886 & 222102 & Merged with lake 460 \\
\hline 462 & East Hungu 2 & $27^{\circ} 48.30^{\prime} \mathrm{N}, 86^{\circ} 58.65^{\prime} \mathrm{E}$ & 5483 & 640 & 448 & 459 & 211877 & 178317 & 164098 & Area decreasing \\
\hline 464 & Unnamed & $27^{\circ} 46.86^{\prime} \mathrm{N}, 86^{\circ} 57.22^{\prime} \mathrm{E}$ & 5205 & 1100 & 1918 & 2251 & 349397 & 783553 & 835131 & Growing in size \\
\hline 466 & W. Chamiang & $27^{\circ} 45.24^{\prime} \mathrm{N}, 86^{\circ} 57.33^{\prime} \mathrm{E}$ & 4983 & 125 & 1699 & 1698 & 6446 & 831427 & 852858 & 465-469 merged into one \\
\hline
\end{tabular}



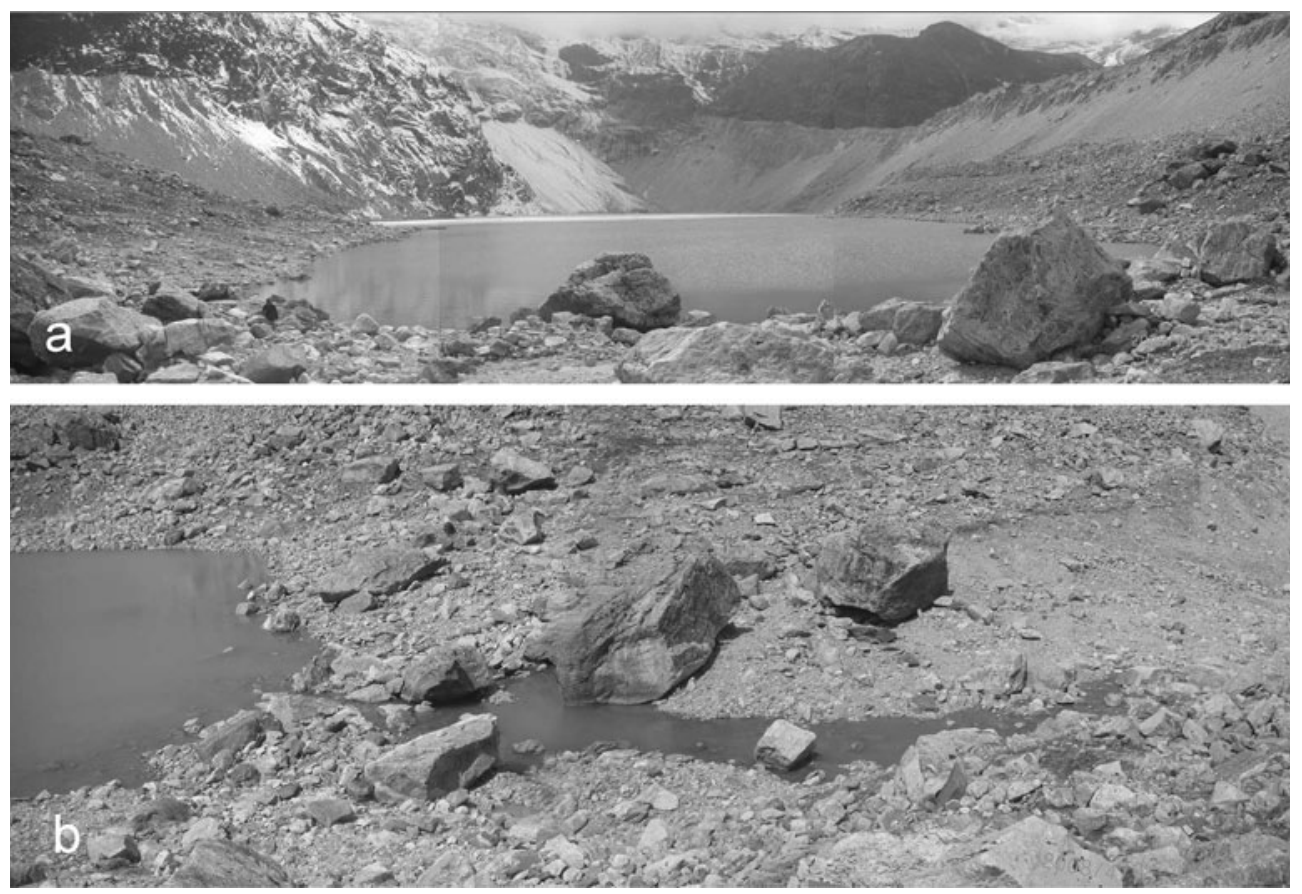

Fig. 3. Dig Tsho is no longer a threat, as the lake outlet and river bed are at the same level. (a) Dig Tsho in April 2008. (b) Outlet of Dig Tsho and Langmoche river bed.

Reynolds, 2000; Mool and others, 2001; Kattelmann, 2003). A number of GLOFs have already been reported in this region (Yamada and Sharma, 1993; Mool, 1995; Reynolds, 1998; Yamada, 1998, 2000; Mool and others, 2001; Bajracharya and others, 2007), such as the Nare GLOF (1977), the Dig Tsho GLOF (1985), the Tam Pokhari GLOF (1998) and one from lake 458/459 (associated with glacier 260) inferred from satellite imagery.

Only the Dig Tsho GLOF is well documented. Vuichard and Zimmermann (1987) reported that a $10-20 \times 10^{4} \mathrm{~m}^{3}$ ice mass dislodged itself from the overhanging Langmoche Glacier and plunged into the lake, inducing a dynamic wave. The flood began in the early afternoon and lasted for 4-6 hours. The peak flood was estimated at $1600 \mathrm{~m}^{3} \mathrm{~s}^{-1}$, but Cenderelli and Wohl $(2001,2003)$ consider the peak discharge to be of the order of $2350 \mathrm{~m}^{3} \mathrm{~s}^{-1}$. The mean velocity of the surge front was $4-5 \mathrm{~m}^{3} \mathrm{~s}^{-1}$ (Vuichard and Zimmermann, 1987). Multiple surges were also reported; for example, the bridges at the villages of Jorsalle, Phakding and Jubing were not destroyed until 30-90 min after the passage of the initial surge. The most significant impact of this GLOF was the complete destruction of a new hydropower station at Thamo and about 30 houses, and the loss of 14 bridges between Mingbo and Jubing. The social, economic and environmental consequences of this GLOF were devastating. Because of the destruction of forest and inundation of cultivable land, villagers lost their subsistence base. The erosion from the surge along the river valley left active scars where further erosion was accelerated by wind, snow, rain and undercutting by the river. Even though Dig Tsho stabilized, the settlements, cultivated land and forests are still at threat from landslides and further erosion.

The past record shows that at least one GLOF event occurs every 3-10 years in the Himalayan region (Bajracharya and others, 2008), but with rising temperatures and more variability in the climate the frequency of GLOF events is expected to increase in the coming years.

\section{CONCLUSIONS}

The Dudh Koshi basin is the largest glacierized basin in Nepal. It has 278 glaciers of which 40 , amounting to $70 \%$ of the area, are valley-type. Almost all the glaciers are retreating at rates of $10-59 \mathrm{~m} \mathrm{a}^{-1}$, but the rate for some has accelerated during the last half-decade to $74 \mathrm{~m} \mathrm{a}^{-1}$. This fast and continuous retreat of glaciers has resulted in a proliferation of major glacial lakes to 34 and the creation of 24 new ones at 4349-5636 ma.s.l. The basin is threatened by 12 potentially dangerous glacial lakes, but following further fieldwork two of these can now be removed from the list. Expanding glacial lakes may pose additional dangers in the near future, so adequate monitoring of glaciers and their lakes is vital for the sound management of water resources and disaster mitigation. A major challenge is how to accomplish this, considering the limits imposed by high altitude, the rarefied atmosphere, the remoteness of most locations and the short mapping season.

\section{REFERENCES}

Albert, T.H. 2002. Evaluation of remote sensing techniques for icearea classification applied to the tropical Quelccaya ice cap, Peru. Polar Geogr., 26(3), 210-226.

Bajracharya, S.R. and P.K. Mool. 2005. Growth of hazardous glacial lakes in Nepal. In Yoshida, M., B.N. Upreti, T.N. Bhattarai and S. Dhakal, eds. Proceedings of the JICA Regional Seminar on Natural Disaster Mitigation and Issues on Technology Transfer in South and Southeast Asia, 30 September - 13 October 2004, Kathmandu, Nepal. Kathmandu, Tribhuvan University, TriChandra Campus, Department of Geology with Japan International Cooperation Agency 131-148.

Bajracharya, S.R., P.K. Mool and B. Shrestha. 2007. Impact of climate change on Himalayan glaciers and glacial lakes: case studies on GLOF and associated hazards in Nepal and Bhutan. Kathmandu, International Centre for Integrated Mountain Development and United Nations Environmental Programme Regional Office Asia and the Pacific. (ICIMOD Publication 169.). 
Bajracharya, S.R., P.K. Mool and B.R. Shrestha. 2008. Global climate change and melting of Himalayan glaciers. In Ranade, P.S., ed. Melting glaciers and rising sea levels: impacts and implications. Hyderabad, Icfai University Press.

Bolch, T., M.F. Buchroithner, J. Peters, M. Baessler and S. Bajracharya. 2008. Identification of glacier motion and potentially dangerous glacial lakes in the Mt. Everest region/ Nepal using spaceborne imagery. Natur. Hazards Earth Syst. Sci. (NHESS), 8(6), 1329-1340.

Cenderelli, D.A. and E.E. Wohl. 2001. Peak discharge estimates of glacial-lake outburst floods and 'normal' climatic floods in the Mount Everest region, Nepal. Geomorphology, 40(1-2), 57-90.

Cenderelli, D.A. and E.E. Wohl. 2003. Flow hydraulics and geomorphic effects of glacial-lake outburst floods in the Mount Everest region, Nepal. Earth Surf. Process. Landf., 28(4), 385-407.

Fujita, K., T. Kadota, B. Rana, R.B. Kayastha and Y. Ageta. 2001. Shrinkage of Glacier AX010 in Shorong region, Nepal Himalayas in the 1990s. Bull. Glaciol. Res., 18, 51-54.

Hambrey, M.J., D.J. Quincey, N.F. Glasser, J.M. Reynolds, S.J. Richardson and S. Clemmens. 2008. Sedimentological, geomorphological and dynamic context of debris-mantled glaciers, Mount Everest (Sagarmatha) region, Nepal. Quat. Sci. Rev., 27(25-26), 2361-2389.

Houghton, J.T. and 7 others, eds. 2001. Climate change 2001: the scientific basis. Contribution of Working Group I to the Third Assessment Report of the Intergovernmental Panel on Climate Change. Cambridge, etc., Cambridge University Press.

Ives, J.D. 1986. Glacier lake outburst floods and risk engineering in the Himalaya - a review of the Langmoche disaster, Khumbu Himal, 4 August 1985. Kathmandu, International Centre for Integrated Mountain Development. (ICIMOD Occasional Paper 5.)

Kattelmann, R. 2003. Glacial lake outburst floods in the Nepal Himalaya: a manageable hazard? Natur. Hazards, 28(1), 145-154.

Khromova, T.E., M.B. Dyurgerov and R.G. Barry. 2003. Latetwentieth century changes in glacier extent in the Ak-shirak Range, Central Asia, determined from historical data and ASTER imagery. Geophys. Res. Lett., 30(16), 1863. (10.1029/ 2003GL017233.)

Mool, P.K. 1995. Glacier lake outburst floods in Nepal. J. Nepal Geol. Soc., 11, Special Issue, 273-280.

Mool, P.K., S.R. Bajracharya and S.P. Joshi. 2001. Inventory of glaciers, glacial lakes and glacial lake outburst floods: monitoring and early warning systems in the Hindu Kush-Himalayan region, Nepal. Kathmandu, International Centre for Integrated Mountain Development with United Nations Environment Programme/ Regional Resource Centre for Asia and the Pacific.

Oerlemans, J. 1994. Quantifying global warming from the retreat of glaciers. Science, 264(5156), 243-245.

Paul, F. 2002. Combined technologies allow rapid analysis of glacier changes. EOS, 83(23), 253, 260-261.

Paul, F., A. Kääb, M. Maisch, T. Kellenberger and W. Haeberli. 2004. Rapid disintegration of Alpine glaciers observed with satellite data. Geophys. Res. Lett., 31(21), L21402. (10.1029/ 2004GL020816.)

Reynolds, J.M. 1998. High-altitude glacial lake hazard assessment and mitigation: a Himalayan perspective. In Maund, J.G. and M. Eddleston, eds. Geohazards in engineering geology. London, Geological Society, 25-34. (Special Publication 15.)

Richardson, S.D. and J.M. Reynolds. 2000. An overview of glacial hazards in the Himalayas. Quat. Int., 65/66(1), 31-47.

Sidjak, R.W. and R.D. Wheate. 1999. Glacier mapping of the Illecillewaet icefield, British Columbia, Canada, using Landsat TM and digital elevation data. Int. J. Remote Sens., 20(2), 273-284.

Vuichard, D. and M. Zimmermann. 1987. The 1985 catastrophic drainage of a moraine-dammed lake, Khumbu Himal, Nepal: cause and consequences. Mt. Res. Dev., 7(2), 91-110.

Watanabe, T., J.D. Ives and J.E. Hammond. 1994. Rapid growth of a glacial lake in Khumbu Himal, Himalaya: prospects for a catastrophic flood. Mt. Res. Dev., 14(4), 329-340.

Watanabe, T., S. Kameyama and T. Sato. 1995. Imja Glacier deadice melt rates and changes in a supra-glacial lake, 1989-1994, Khumbu Himal, Nepal: danger of lake drainage. Mt. Res. Dev., 15(4), 292-300.

Yamada, T. 1998. Glacier lake and its outburst flood in the Nepal Himalaya. Tokyo, Japanese Society of Snow and Ice. Data Center for Glacier Research. (Monograph 1.)

Yamada, T. 2000. Glacier lake outburst floods in Nepal. Seppyo, J. Jpn. Soc. Snow Ice, 62(2), 137-147. [In Japanese with English summary.]

Yamada, T. and C.K. Sharma. 1993. Glacier lakes and outburst floods in the Nepal Himalaya. IAHS Publ. 218 (Symposium at Kathmandu 1992 - Snow and Glacier Hydrology), 319-330.

Zimmermann, M., M. Bischel and H. Keinholz. 1986. Mountain hazards mapping in the Khumbu Himal, Nepal, with prototype map, scale 1:50,000. Mt. Res. Dev., 6(1), 29-40. 